\title{
A EXPERIMENTAÇÃO DO RISCO NA CARREIRA CRIATIVA: \\ o caso de mestres da cultura do artesanato cearense
}

1- Márcia de Freitas Duarte

Doutoranda em Administração de Empresas pela Fundação Getúlio Vargas (EAESP/FGV), Brasil. marcia.freitas.duarte@gmail.com

http://lattes.cnpq.br/6011463057600858

\section{2- André Luis Silva}

Doutorando em Administração de Empresas pela Fundação Getúlio Vargas (EAESP/FGV), Brasil. andre.luis.silva@gvmail.br

http://lattes.cnpq.br/1257050194773665

\author{
Diego Maganhotto Coraiola - Editor Geral \\ Editor responsável pela submissão: \\ Diego Maganhotto Coraiola. \\ Artigo analisado via processo de revisão duplo cego (Double-blind). \\ Recebido em: 09/03/2013 \\ Aprovado em: 15/05/2013 \\ Última Alteração: 20/05/2013
}

* Contato Principal: Rua Itapeva, 474, sala 1104. Bela Vista, São Paulo - SP, Brasil. CEP: 01332-000. 


\section{A EXPERIMENTAÇÃO DO RISCO NA CARREIRA CRIATIVA: O CASO DE MESTRES DA CULTURA DO ARTESANATO CEARENSE}

\section{RESUMO}

Neste artigo, argumentamos que o risco se tornou um elemento cada vez mais presente para as pessoas na experimentação da vida contemporânea, sobretudo no aspecto profissional. Sendo uma pesquisa teóricoempírica de natureza qualitativa, investigamos a forma como o risco é experimentado em carreiras criativas, neste caso, especificamente, em carreiras de artesãos detentores do título de “Mestres da Cultura Tradicional Popular", concedido pelo Governo do Estado do Ceará. Articulando a literatura acerca de risco e carreiras criativas junto aos relatos das experiências dos entrevistados, concluímos que, embora haja divergências nos fatores de proteção mobilizados pelos artesãos para lidarem com o risco em suas vidas profissionais, eles encararam e guiaram seus comportamentos frente a essa experimentação de modos muito similares. Foi a partir dessas similaridades que os artesãos conseguiram repensar os seus modos de trabalho; descobrir alternativas para lidar com a experimentação do risco em suas vidas; encontrar maneiras para pensarem os significados de seu ofício; e, por fim, elaborar modos alternativos para permanecerem na construção de suas carreiras criativas.

Palavras-chave: artesão; risco; carreira criativa; trabalho; vida profissional.

\section{THE RISK EXPERIMENTATION IN THE CREATIVE CAREER: THE CASE OF MASTERS OF THE CEARENSE CULTURE CRAFT}

\section{ABSTRACT}

Risk has become ever more present during the experimentation of contemporary life, particularly in the professional field. From this argument, this qualitative research investigates how the risk is experienced or lived in creative careers, specifically, in careers of artisans awarded with the title of "Masters of Traditional Popular Culture", granted by the State Government of Ceará. We articulate the literature on risk and creative careers together with the reports of the experiences of the respondents in a such way that led us conclude that although there are differences in protection factors mobilized by artisans to deal with risk in their professional lives, they faced and guided their behavior to face such experiments in very similar ways. Parting from these similarities, the craftsmen: rethought the ways of doing their work; found alternatives to deal with the experimentation of risk in their lives; discovered new ways to think about the meanings of their craft; and developed alternative ways to continue to develop their creative careers.

Keywords: artisan; risk; creative career; work; professional life. 


\section{Introdução}

O pressuposto central desta pesquisa consiste na ideia de que o risco se tornou um elemento cada vez mais presente para as pessoas na experimentação da vida contemporânea, sobretudo no aspecto profissional. Isto porque, em meio às constantes metamorfoses sociais, econômicas e políticas, a esfera do trabalho humano foi crescentemente envolvida pela imprevisibilidade decorrente dessas mutações. As pessoas são, pois, fortemente impactadas ao terem comprometida a continuidade de suas carreiras frente ao abalado ambiente profissional que se impôs de modo predominante. É na experimentação desses impactos que a percepção de risco das pessoas emerge como um elemento presente das carreiras contemporâneas.

Certamente o ciclo de impactos e mudanças no mundo do trabalho tem afligido as mais distintas áreas, contextos e profissões. Sobretudo, tem impactado os indivíduos que não possuem vínculos de trabalhos em organizações formais, dentre os quais, os profissionais criativos. Para estes profissionais, destituídos de amparo organizacional e seus benefícios trabalhistas - ao contrário dos profissionais sob vínculo formal de trabalho - a percepção do risco se mostra mais facilmente e com maior frequência, posto que suas carreiras são guiadas quase que exclusivamente por suas ações e decisões individuais.

Mas chama atenção o fato de que o debate sobre a relação entre a percepção de risco e os impactos na carreira criativa cria a possibilidade de se compreender como se articula o elemento risco com os demais relativos às carreiras desses profissionais seja em relação às competências criativas, técnicas ou empreendedoras na indústria criativa. Considerando essa configuração, levantamos a seguinte pergunta: como os artesãos da indústria criativa do artesanato experimentam o risco em suas vidas profissionais? Oferecer uma resposta para tal questionamento ao se investigar a forma como o risco é experimentado em carreiras criativas é, portanto, o objetivo central deste estudo.

A base empírica desta pesquisa foi produzida a partir dos relatos das experiências de artesãos detentores do título de "Mestres da Cultura Tradicional Popular" ou "Tesouros Vivos da Cultura", concedido pelo Governo do Estado do Ceará (SECULT-CE, 2009). Embora seja este um título de reconhecimento simbólico sobre a importância do artista popular no contexto cultural do referido Estado, consideramos que esse reconhecimento pode exercer um papel peculiar sobre as formas como esses artesãos experimentam o risco em suas carreiras e, portanto, nos dará subsídios importantes para atingir o objetivo pleiteado nesta pesquisa.

Além desta introdução, o artigo segue estruturado da seguinte maneira: primeiramente indicamos as premissas teóricas que norteiam o termo risco. Em seguida apresentamos concepções teóricas a cerca das carreiras criativas. Na sequência, para nos situarmos sobre as especificidades do contexto em estudo, delineamos algumas noções sobre as características da indústria criativa do artesanato no Brasil. Na seção seguinte, detalhamos os procedimentos metodológicos desta pesquisa. Posteriormente realizamos a articulação entre os dados empíricos do estudo e a base teórica previamente levantada. Por fim, a última seção registra e detalha as conclusões obtidas nesta pesquisa.

\section{O Risco na Vida Contemporânea}

O termo risco foi utilizado inicialmente por marinheiros e investidores marítimos a partir do século XVII. O termo era associado à probabilidade de um evento negativo ocorrer durante o transporte de cargas e mercadorias por vias marítimas. Nesse contexto, os eventos negativos incluíam exemplos tais como: doença, morte dos tripulantes das navegações e o impacto gerado pelo custo das perdas associadas às cargas e mercadorias que eram transportadas (Mizruchi, 2009).

Mais tarde, no contexto do conhecimento cientifico, o conceito de risco foi utilizado na área das ciências da saúde, tendo suas origens na epidemiologia. O foco era estudar os padrões pelos quais uma doença se manifestava em determinadas populações e, por conseguinte, os fatores que influenciavam estes padrões (Masten \& Garmezy, 1985). Na área da saúde, o conceito de risco também foi utilizado em estudos psicossociais e socioculturais, quando o objetivo estava em conhecer o processo de desenvolvimento das pessoas em relação a fatores críticos, como: fatores de pobreza; analfabetismo; miséria e estruturas familiares fragilizadas por conflitos físicos e/ou psicológicos de cunho agressivo. Um dos estudos com este tipo de enfoque é o de Raffaelli et al. (2007), o qual buscou compreender a relação entre o ajustamento psicossocial de jovens brasileiros de baixa renda a três tipos de fatores de risco: o comunitário - local onde residem; o econômico - aspectos relacionados à renda financeira; e o familiar - o estado civil e nível educacional dos pais desses jovens. Os resultados da pesquisa indicam que os efeitos negativos da exposição dos jovens brasileiros de baixa renda a fatores de riscos, se associam ao decréscimo de sua capacidade psicológica, comportamental, e de ajustamento social. De modo geral, as pesquisas a respeito da exposição das pessoas ao risco, assimilam que os fatores de risco "relacionam-se com toda sorte de eventos negativos da vida, e que, quando presentes, aumentam a probabilidade de o indivíduo apresentar problemas físicos, sociais ou emocionais" (Yunes \& Szymanski, 2001, p. 24).

Já no contexto das ciências sociais, o conceito de risco foi trabalhado por diversos pesquisadores, dentre eles Beck (2007). Para este autor, o risco é visto como os eventos negativos da vida, oriundos das mudanças sociais configuradas pela sociedade moderna, que impactam as pessoas que os vivenciam. É nesse sentido que Beck (2007), argumenta que a sociedade moderna se tornou uma "sociedade de risco" para as pessoas, à medida que ela se ocupa, cada vez mais, em debater, prevenir e administrar o risco que ela mesma produz. 
Há de se observar que a expressão “sociedade de risco" se difundiu em debates sobre as mudanças sociais ocorridas a partir do início dos anos 2000. Essa expressão representa a necessidade de compreender e aceitar que a incerteza e a imprevisibilidade são cada vez mais inerentes a vida - seja em sua esfera individual ou coletiva - o que exige uma maior reflexividade na construção das biografias de cada indivíduo para que, assim, seja possível delinear os rumos de seus destinos coletivos (Alves, 2009). No entanto, esta reflexividade não se estabelece com facilidade, pois as decisões dos indivíduos perante o risco representam uma relação eminentemente ambígua. Isto é, ao ter de tomar uma decisão perante um fator de risco, o indivíduo pondera entre as possíveis oportunidades e perdas que decorreram de sua escolha frente à situação. Essa ambiguidade é que faz as decisões perante o risco corresponderem a um conhecimento que envolve o trato com incertezas (Beck, 2007).

Ao se defrontarem com a ambiguidade das vivências sociais guiadas pela sensação de incerteza, os indivíduos passam a experimentar uma espécie de desmoronamento das concepções tradicionais da vida em sociedade. Como indica Bauman (2005), se antes as ideologias eram elaboradas com a pretensão de serem abrangentes, exaustivas e duradouras, na vida contemporânea, tudo passa a fluir de maneira mais rápida, de modo que o certo de ontem, hoje não mais o é. Vive-se assim num tempo de transformações sociais aceleradas, caracterizado pela dissolução dos laços afetivos e vínculos sociais entre os indivíduos. Seria esse comportamento, pois, reflexo de uma espécie de liquefação do que antes era considerado sólido e oferecia segurança existencial explicita, já que na atual sociedade vigoram o desapego e a provisoriedade das relações entre os indivíduos e, desse modo, a sensação de incerteza frente às situações que se impõem em suas trajetórias na vida contemporânea.

Não por acaso, ao lidar com uma constante sensação de incerteza, é esperado que, nos indivíduos, surjam sentimentos como a insegurança, angústia e ansiedade, vez que esses sentimentos derivam da impossibilidade em se deter controle sobre os seus futuros. Esses sentimentos negativos atuam, pois, como elementos do risco presentes na sociedade moderna (Beck, 2007). É inevitável que esses elementos criem condições favoráveis para que, nos indivíduos, surja uma condição de desequilíbrio emocional, de modo que a vivência constante sob o elemento risco, na sociedade contemporânea, gera circunstâncias que bifurcam o percurso das trajetórias de vida de forma instável e, portanto, imprevisível (Brüseke, 2001).

O estudo do risco no contexto da sociedade moderna ainda se aprofunda sobre outras importantes áreas, dentre as quais, a do mundo do trabalho. Como indica Job (2003), nessa área, o risco refere-se aos fatores que fragilizam as condições de trabalho fornecidas para as pessoas em seus contextos profissionais. Ademais, no contexto do trabalho nas organizações, o risco refere-se a todos os fatores que tornam as pessoas expostas a situações adversas e que, por conseguinte, as expõem à vivência de uma condição de desequilíbrio emocional que influencia suas vidas pessoais e profissionais (Rutter, 2007).

Como podemos observar, o risco está envolvido nas mais distintas esferas da vida contemporânea. Mas se por um lado é possível reconhecer que existem fatores de risco mediando às relações das pessoas em sociedade, também há de se enfatizar que, por vezes, as pessoas lançam mão da capacidade de mobilizar fatores de proteção para o enfrentamento dos impactos do risco (Cowan et al., 1996; Masten, 2007; Scholz et al., 2012), pois, assim, elas conseguem administrar a própria subjetividade e compreender a situação para se defender (Barlach, 2005; Barlach \& Malvezzi, 2010). Entre alguns exemplos de fatores de proteção estão: a autonomia do indivíduo; sua autoestima; autodeterminação; respeito; reconhecimento; participação da família; amigos; esperança; delimitação de significados para a vida; a preservação de sua identidade; as crenças individuais; autoafirmação; e fé (Job, 2003).

Mas se por um lado algumas pessoas conseguem enfrentar os impactos negativos do risco por meio de fatores de proteção, faz-se relevante reconhecer que existe uma relação dual entre o que vem a ser um fator de risco ou um fator de proteção para uma pessoa. Isto porque, a percepção de ameaça frente ao risco advém dos significados que a pessoa atribui aos eventos estressantes que vivencia, fazendo com que tais eventos exerçam diferentes impactos sobre os indivíduos (Rutter, 2007). Ou seja, por mais que um conjunto de indivíduos partilhe a experiência de se defrontar com um mesmo fator de risco, possivelmente, os fatores de proteção mobilizados para lidar com o risco e, por sua vez, os significados atribuídos à situação, serão diferentes de indivíduo para indivíduo, afinal a experimentação do risco tende a ser vivenciada de maneiras muito distintas entre as pessoas (Rutter, 2007; Reppold et al., 2012).

Ao ser o risco experimentado de modos diferenciados pelos indivíduos, é possível pensá-lo como um processo que instiga transformações internas nos modos de agir das pessoas. Pois, para Yunes e Szymanski (2001), as pessoas, ao se defrontarem com um fator de risco, agem e se comportam de maneiras diferentes, em face dos distintos momentos de suas vidas. Em decorrência do momento/situação que as pessoas vivenciam ao se defrontarem com um fator de risco, por vezes, elas passam a compreender a vida de outra maneira e, portanto, o risco pode ser sempre pensado como um processo.

Sendo o risco um processo que gera transformações nas pessoas, Jeolás (2010), acrescenta que existem diversas maneiras de se vivenciar e expressar o risco, ou seja, existem diversas formas do risco se manifestar e serem significadas ao longo da vida. Por exemplo, existem formas de manifestação do risco que são mais calculadas, planejadas e procuradas, tal como quem opta por praticar esportes radicais; outras formas já são causadas por vulnerabilidades sociais e individuais, dentre elas o risco das drogas e da gravidez na adolescência; já outras maneiras são negadas e não desejadas pelos indivíduos, como a violência urbana; e também existem outras formas de manifestação do risco que são aceitas e até mesmo valorizadas socialmente 
tal como as competições esportivas que exigem abrupto contato físico, como os combates de lutas marciais. Em suma, a manifestação do risco na vida dos indivíduos ora se dá de modo mais coletivo ora de maneira mais individualizada. Contudo, é a partir da forma como a pessoa compreende e significa o determinado fator de risco, que ela experimentará, em maior ou menor grau, os impactos da situação em sua vida.

Considerando o fato de que as pessoas significam os fatores de risco de modos distintos em suas vidas, ao que parece, não existem determinações ou receitas prontas para se lidar com os impactos negativos gerados por esses fatores, uma vez que a forma de se lidar com o risco é distinta de pessoa para pessoa (Barlach et al., 2008; Vergara, 2008). Contudo, neste artigo, partimos do entendimento de que identificar os fatores de risco vivenciados por um determinado grupo de profissionais, pode contribuir para que compreendamos a forma como os diferentes indivíduos desse grupo vivenciaram e significaram essa experiência ao longo de suas trajetórias. Portanto, sendo o foco deste estudo conhecer a experimentação do risco na carreira de artesãos, a seguir, serão apresentadas concepções teóricas acerca das temáticas carreiras criativas e indústria criativa do artesanato.

\section{Carreiras Criativas}

O conceito de classe criativa foi proposto por Florida (2002) para se referir às pessoas que lidam em situação de trabalho com tarefas essencialmente criativas. Independentemente de serem artistas, engenheiros, músicos, cientistas da computação, escritores ou empreendedores, os trabalhadores da classe criativa têm em comum um certo "ethos criativo", compreendido como um espírito de criação que valoriza a capacidade criadora, a inventividade, a individualidade, o fazer diferente como princípio gerador e o mérito associado com as características individuais. Isto faz com que esse "ethos criativo" exerça certa influência nos indivíduos em relação as suas escolhas relativas: ao trabalho; as preferências por determinados tipos de emprego; preferências de consumo; a própria organização do tempo entre trabalho e atividades de lazer; além das decisões relativas ao onde viver.

Em face da conceituação ampla que envolve o entendimento sobre classe criativa, Howkins (2005) cunhou mais especificamente a expressão "empreendedores criativos" para se referir aos empreendedores que atuam nas indústrias criativas. Para a UNCTAD (2008), os empreendedores criativos sujeitam-se às mesmas dificuldades enfrentadas pelas pequenas empresas em outras áreas da economia. A diferença reside no fato de que a gestão de um negócio criativo requer habilidades específicas tanto no campo do empreendedorismo como nas áreas artística e cultural.

Nesse sentido, Eikhof e Haunschild (2006) ressaltam o usual conflito existente entre arte e negócios, evidenciado em situações em que o artista precisa exercer, de modo simultâneo, atividades criativas e negociais. Esse esforço direcionado simultaneamente à negociação e o gerenciamento da sua própria força de trabalho, costuma ser bastante problemático para as pessoas que atuam na indústria criativa. Menger (1999) explica que esses "empreendedores de si mesmos" se veem diante da dificuldade de articular duas identidades distintas: a de artista, que Ihes proporciona motivação e ímpeto criativo; e a empresarial, a qual Ihes provê condições objetivas de sobrevivência e de desenvolvimento profissional e empresarial. Sobre este conflito, Lima (2007) ressalta o fato de que muitos artistas não apreciam assuntos econômicos no seu trabalho, por visualizarem o mercado e a rotina como elementos cerceadores que atentam à liberdade artística.

Ao pesquisarem as carreiras artísticas ou criativas, Bendassolli e Wood Jr. (2010) afirmam que estas são construídas em processos contínuos de encadeamento entre o indivíduo agente e seu ambiente, neste caso, o das indústrias criativas. Para compreender a dinâmica e os paradoxos implicados nessas concatenações, os autores sugerem duas díades ou possibilidades. A primeira refere-se ao amadorismo e profissionalismo, no sentido de que a pessoa pode optar, na construção de sua carreira, pela manutenção da atividade artística como um hobby, algo que se possa fazer nas horas vagas. Isso pode the propiciar maior liberdade; porém, o desenvolvimento de sua carreira artística terá de competir com a necessidade de uma outra "profissão", para assegurar sua sobrevivência. A segunda díade ocorre entre a opção por uma valorização intrínseca do trabalho ou, em contrapartida, por uma valorização extrínseca. No primeiro caso, o artista pode orientar-se pelos atributos pessoais de seu trabalho, como a concepção de arte e criação como um "pôr para fora" de insights que nem sempre convergem com as demandas e o "timing" exigidos pela audiência e mercado. Em contrapartida, o valor atribuído pelo público depende de um processo de significação extrínseca, cabendo ao artista ou profissional um esforço de identificação e adaptação. O desencontro entre essas duas formas de significação do trabalho pode gerar frustração no artista ou no público.

Considerando os argumentos apresentados até o momento sobre risco e carreiras criativas, consideraremos, para esta pesquisa, que a percepção de risco e as ações e comportamentos voltados ao enfrentamento de tais situações decorre do imperativo vivenciado pelos profissionais criativos em relação à conciliação de duas identidades distintas: a artística ou criativa e a empresarial ou empreendedora. Entendemos que a primeira refere-se à capacidade de exercer o ofício artesanal, comprometendo-se com o caráter artístico, a unicidade e autenticidade de suas criações. A última refere-se às relações do artista com seus clientes e mercado em geral, em benefício da reputação e do valor cultural que sustentam o valor do que produz com o seu trabalho, bem como em prol da realização de parcerias e busca por novos mercados e clientes. Como o foco deste estudo está em conhecer a experimentação do risco em carreiras criativas, mas especificamente, por meio da figura dos artesãos detentores do título de “Mestres da Cultura Tradicional 
Popular", a seguir, indicamos algumas noções sobre o contexto de trabalho desses profissionais. Ou seja, são apresentadas características da indústria criativa do artesanato.

\section{Indústria Criativa do Artesanato}

As indústrias criativas formam um conjunto de setores e atividades que utilizam a criatividade, o talento e as habilidades humanas como principais insumos da produção de um amplo conjunto de bens criativos, desde os mais tradicionais até aqueles que requerem intensa tecnologia. Estes setores apresentam elevado potencial para a geração de propriedade intelectual, ocupações, renda e desenvolvimento local, seja como fator de valorização das tradições locais ou ainda como propulsor de uma nova classe de trabalhadores e de empreendedores baseados na nova economia do conhecimento e da inovação.

Dentre as atividades caracterizadas como indústrias criativas, destaca-se o artesanato, atividade predominantemente manual que exige criatividade, habilidade e destreza (Lima \& Azevedo, 1982), aplicadas na produção de peças diferenciadoras que podem ser utilitárias, estéticas, artísticas, criativas, culturais, decorativas, funcionais, tradicionais ou religiosas (UNESCO, 1997) e que se destacam pela originalidade e representatividade cultural, transformando-as em artefatos únicos (Barros, 2006).

Na literatura sobre indústria criativa, o artesanato está presente em cinco modelos de classificação do setor (DCMS, 2008; Throsby, 2001; Marcus, 2005; DECON, 2008; UNCTAD, 2008). Em Throsby (2001), Marcus (2005) e Decon (2008), o artesanato é inserido em destaque no núcleo da indústria criativa. Não por acaso, conforme dados do IBGE (2007), o artesanato, dentre as atividades culturais e artísticas desenvolvidas no país, destaca-se como uma das principais manifestações culturais brasileiras, presente em 64,3\% dos municípios do país. Possui destaque particular nos estados do Acre, Amazonas, Ceará, Pernambuco, Alagoas, Espírito Santo, Santa Catarina, Rio Grande do Sul, Mato Grosso do Sul e Rio de Janeiro. Também como aponta pesquisa do Ministério do Desenvolvimento, Indústria e Comércio, realizada em 2002, (MDIC, 2002), no referido ano, o Brasil possuía cerca de 8,5 milhões de artesãos, responsáveis por um movimento financeiro anual de R\$ 28 bilhões, correspondente a $2,8 \%$ do Produto Interno Bruto (PIB).

A região Nordeste do Brasil é área de grande tradição cultural e turística, despontando com destaque no artesanato nacional pela variedade e expressividade da sua produção (SEBRAE, 2008). Estudo do Banco do Nordeste, de 2002 (BNB, 2002), registrou um número aproximado de 3,3 milhões de artesãos no Nordeste político. O mesmo estudo associava, de maneira positiva, o artesanato regional ao fluxo turístico, outra atividade relacionada à economia criativa. O referido estudo estima que $76,1 \%$ dos municípios cearenses produzem artesanato de algum tipo, fato que evidencia a importância do setor para o estado.

Do ponto de vista social, Silva (2006) explica que o estímulo ao resgate das atividades econômicas baseadas no fazer manual e na manufatura primitiva representa a inclusão produtiva de segmentos populacionais menos favorecidos. Para a autora, o fato se reveste de maior importância porque esses artesãos costumam desenvolver atividades no espaço do conhecimento informal, aprendido em relacionamentos primários e pela transmissão transgeracional, quase sempre à margem das políticas de ensino formal e das iniciativas de educação para o trabalho. Para Luiz Carlos Barboza, diretor-técnico do SEBRAE (2008), um dos maiores desafios relacionados ao artesanato é a sua transformação em atividade econômica sustentável, de cunho empresarial, por meio da organização de produtores e da estruturação de canais de distribuição, no bojo de uma cadeia produtiva efetiva.

Para isso, Barros (2006) ressalta a necessidade de desenvolver as habilidades de gestão de negócios dos artesãos, para que possam administrar relações com o mercado e a integralidade do processo produtivo e a comercialização. Adicionalmente, Freitas (2006) alerta sobre a importância de capacitar os artesãos para expandir mercados por meio da via associativa e cooperativa, visando o conhecimento da cadeia produtiva e inserção de produtos no mercado nacional e internacional. A expansão do foco local na comercialização desponta, pois, como desafio de base, para que a qualidade do produto final, sua funcionalidade e acabamento sejam condições de sucesso. Assim, o reforço das qualidades empreendedoras do artesão precisam ser buscadas, a fim de que o desenvolvimento de mercados se faça.

Entendemos que o escopo teórico levantado até o momento acerca dos termos: risco; carreiras criativas; e indústria criativa do artesanato; fornece-nos condições para abordar o propósito delimitado para esta pesquisa. Sendo assim, a seguir descrevemos os procedimentos metodológicos que orientam a pesquisa de campo utilizada na composição deste trabalho.

\section{Delineamento Metodológico}

Optamos por um estudo de natureza qualitativa, por estar orientado a uma abordagem subjetivista. Isto é, cujo núcleo de pressupostos ontológicos nos dá condições para se compreender a natureza da realidade social a partir das perspectivas e interpretações das diferentes pessoas envolvidas no evento, fato, processo ou experiência investigada (Cunliffe, 2011).

Em face dessa natureza de pesquisa, este estudo teve o intuito de preservar a riqueza e a expressividade de experiências profissionais não comumente exploradas na literatura sobre carreiras e empreendedorismo na 
indústria criativa. Para atingir esse propósito, este é um estudo do tipo descritivo, por ser um tipo de pesquisa que nos fornece condições de se apreender padrões, características, peculiaridades e trajetórias de um grupo específico de atores sociais (Bluhm et al., 2011). Quanto aos procedimentos utilizados, optamos por uma abordagem baseada na história de vida associada a um estudo de caso múltiplo ou multicasos, aspectos que serão explicitados no decorrer desta seção.

$\mathrm{Na}$ escolha dos participantes da pesquisa, buscamos considerar a diversidade do campo do artesanato, aliada a algum critério que proporcionasse reconhecimento técnico e artístico quanto ao exercício da carreira de artesão. Compreender o desenvolvimento de carreira dos Mestres da Cultura do Tradicional Popular do Ceará pareceu unir os dois aspectos citados anteriormente, pelo fato de que os referidos Mestres tiveram e têm suas vidas e obras voltadas para a cultura tradicional e popular do Ceará, de modo que são reconhecidos publicamente pela representatividade e qualidade do trabalho desenvolvido. Eles possuem assim, experiência e vivência dos costumes e tradições culturais cearenses, possuindo, portanto, capacidade de transmitir seus conhecimentos artísticos e culturais (Ceará, 2008).

Dessa forma, estabelecemos os seguintes critérios: a) ser detentor do título de Mestre / Tesouro Vivo da Cultura Tradicional Popular do Ceará; e b) desenvolver atividades no campo do artesanato. Na época em que a coleta de dados foi realizada, no mês de novembro de 2009, realizamos tentativas de contato com os 10 (dez) Mestres da Cultura que realizavam atividades artesanais na época. Desses, 02 (dois) estavam impossibilitados de participar da pesquisa devido a problemas de saúde e 02 (dois) não foram localizados. Assim, o estudo cobre 6 (seis) dos 10 (dez) detentores do título até o momento em que a pesquisa foi realizada, o que permite uma visão satisfatória do campo. Este procedimento configura-se como não probabilístico e baseado na acessibilidade. A seguir, a Figura 1, apresenta uma síntese das informações pertinentes ao conjunto de participantes que compõe a base empírica utilizada nesta pesquisa. Ressaltamos que essas informações refletem a configuração obtida no momento da coleta dos dados no ano de 2009.

\begin{tabular}{|c|c|c|c|c|c|}
\hline \multicolumn{7}{|c|}{ Informações pertinentes sobre os artesões entrevistados } \\
\hline Nome & $\begin{array}{c}\text { Nome } \\
\text { artístico }\end{array}$ & Idade & $\begin{array}{c}\text { Cidade onde } \\
\text { reside }\end{array}$ & $\begin{array}{c}\text { Atividade } \\
\text { desenvolvida }\end{array}$ & $\begin{array}{c}\text { Ano do } \\
\text { diploma }\end{array}$ \\
\hline $\begin{array}{c}\text { Maria de Lourdes } \\
\text { Cândido Monteiro }\end{array}$ & Maria Cândido & 70 & Juazeiro do Norte & Artesanato em barro & 2004 \\
\hline $\begin{array}{c}\text { Lúcia Rodrigues da } \\
\text { Silva }\end{array}$ & Lúcia Pequeno & 50 & Limoeiro do Norte & $\begin{array}{c}\text { Artesanato em cerâmica } \\
\text { e barro }\end{array}$ & 2004 \\
\hline $\begin{array}{c}\text { Francisca R. Ramos } \\
\text { do Nascimento }\end{array}$ & Dona Francisca & 70 & Viçosa do Ceará & Arte em Cerâmica & 2005 \\
\hline $\begin{array}{c}\text { Pedro Alves da Silva } \\
\text { Maria de Castro } \\
\text { Firmeza }\end{array}$ & Pedro Balaieiro & 83 & Guaramiranga & $\begin{array}{c}\text { Artesanato com trançado } \\
\text { em cipó e imbé }\end{array}$ & 2006 \\
\hline $\begin{array}{c}\text { Espedito Veloso de } \\
\text { Carvalho }\end{array}$ & $\begin{array}{c}\text { Espedito } \\
\text { Seleiro }\end{array}$ & 70 & Nova Olinda & Arte em couro & 2008 \\
\hline
\end{tabular}

Figura 1 - Síntese das informações sobre o conjunto de entrevistados da pesquisa

Fonte: elaborado pelos autores a partir dos dados obtidos nas entrevistas.

Em face da disponibilidade em ir ao encontro dos artesãos para realizar a coleta de dados, a pesquisa de campo ocorreu nos diferentes municípios cearenses onde residem os artesãos. A abordagem utilizada foi a história de vida, associada à técnica de entrevistas semiestruturadas. As histórias de vida se constituem de narrativas produzidas com a intenção de transmitir memórias dos próprios sujeitos engajados no fenômeno em estudo (Santamarina \& Marinas, 1999). Por meio desta técnica é possível se captar o que acontece na intersecção do individual com o social dando condições para se perceber quais são os elementos do presente que se fundam com evocações passadas (Paulilo, 1999). Conforme Meihy (2002), as histórias de vida estão inseridas no amplo quadro da história oral, a qual apresenta outras modalidades ou classificações. Sob essa perspectiva, este estudo apresenta-se como história oral temática e da história oral de vida. Trata-se de história oral temática porque há certa objetividade ao partir de um assunto específico, no caso, a carreira ou trajetória profissional dos artesãos. No entanto, há fortes elementos de história oral de vida, já que os participantes tiveram autonomia para dissertar o mais livremente possível sobre sua experiência pessoal e profissional. Podemos ainda entender esta pesquisa também como um estudo de caso múltiplo ou multicasos (Gil, 2002; Triviños, 2007), pois a história de vida de cada artesão é compreendida como um estudo de caso em si.

A aplicação da técnica de história de vida ocorreu acima de tudo na forma como conduzimos a elaboração do roteiro de entrevista e na maneira como estas foram conduzidas. Optamos por realizar entrevistas semiestruturadas, as quais permitiam aliar temas pré-definidos e a liberdade e a espontaneidade necessárias para relatar fatos e momentos da vida profissional, enriquecendo assim, a investigação (Triviños, 2007) e aproximando-nos da abordagem da história de vida. Nosso roteiro foi elaborado e segmentado em seis blocos, a partir do referencial teórico acerca do desenvolvimento de carreiras criativas e conforme os objetivos propostos pela pesquisa. Isto é, abordamos as temáticas: trajetória profissional; atividade artesanal; capacitação; reconhecimento; desafios enfrentados; e situação atual. 
Partindo desse roteiro semiestruturado, permitimos que os artesãos, no momento da entrevista, tivessem a liberdade de narrar suas histórias de vida e memórias como melhor lhes convinha, de forma que os mesmos puderam ressaltar relevantes aspectos de suas carreiras e também de sua vida pessoal e do contexto histórico, cultural e social em que suas atividades profissionais foram e vinham sendo desenvolvidas. Com tal postura, acreditamos que a utilização das histórias de vida mostrou-se pertinente por contribuir para a construção das narrativas e memórias acerca das trajetórias profissionais dos sujeitos de pesquisa, a partir do seu próprio relato e, com isso, proporcionou uma compreensão mais detalhada acerca do desenvolvimento de suas carreiras.

O conjunto de dados reunidos ao fim da pesquisa de campo foram interpretados por meio do procedimento analítico geral (Collis \& Hussey, 2005; Milles \& Huberman, 1994), tendo os conteúdos das entrevistas sido organizados por meio de categorias temáticas pré-definidas e selecionadas a partir das teorias concernentes e também dos dados que emergiram em campo. Assim, a análise dos dados foi procedida sobre as seguintes categorias: caracterização da atividade artesanal; inserção profissional na carreira de artesão; desenvolvimento e gestão da carreira; reconhecimento artístico e econômico; desafios ao longo da carreira; e perspectivas atuais de carreira e negócios. Ao longo do processo de interpretação dos dados surgiram alguns aspectos inusitados que convergem para o escopo do estudo. Surgiram, por exemplo, como situações similares de riscos foram enfrentadas pelos mesmos, na medida em que, foi possível identificar quais foram os fatores de proteção utilizados por eles para lidarem com essas situações ao longo de suas vidas profissionais. Muitos dos resultados obtidos nesse processo serão apresentados a seguir por meio da descrição individual dos casos, com base nas categorias levantadas ao longo do processo de interpretação do conjunto de dados.

\section{Apresentação e Interpretação dos Dados}

Com a finalidade de compreender a forma como o risco tem sido experimentado em carreiras criativas, coletamos relatos das experiências de artesãos detentores do título de "Mestres da Cultura Tradicional Popular" ou "Tesouros Vivos da Cultura", concedido pelo Governo do Estado do Ceará (SECULT-CE, 2009). A seguir, são apresentados e interpretados esses relatos para que seja possível, em seguida, realizar as discussões conclusivas desta pesquisa.

\subsection{Espedito Seleiro}

Espedito Veloso de Carvalho (Espedito Seleiro) nasceu em Arneiroz-CE, em 1939. Reside em Nova Olinda$\mathrm{CE}$, onde exerce suas atividades profissionais como artesão na tipologia couro. Destaca-se pela produção de sapatos, sandálias, bolsas e artigos para vaqueiros. Foi diplomado Mestre/Tesouro Vivo da Cultura em 2008. Ao longo de sua carreira como artesão, Espedito Seleiro enfrentou uma série de situações adversas, dentre elas: a ausência de capital para investir; o laborioso trabalho necessário para atender as características do tipo de peças que produzia; e as dificuldades para aumentar sua produção. Nesse sentido, Espedito Seleiro ressalta que sua maior dificuldade no início da carreira, isto é, em 1957, aos seus 18 anos, era a ausência de capital para investir:

Mas num tinha dinheiro pra comprar matéria-prima pra você fazer bem muita coisa assim do jeito que você desejava. Mas você tem que ir com paciência porque se você for de uma vez você desvanece e não um chega lá de jeito nenhum. E foi o que eu fiz [...] O dinheiro era pouco, mas eu comprei o deu pra comprar e até hoje nunca mais eu parei [ ...] Aí fica ruim né, mas de qualquer maneira, tendo calma, Deus lhe ajuda e você chega onde você tem vontade (sic).

Neste trecho do relato de Espedito Seleiro percebe-se que a questão do capital insuficiente para investir em trabalho, emergiu para ele como um fator de risco. Nota-se que este fator de risco impactou, de certo modo, suas condições de trabalho. Esta evidência vai ao encontro do argumento de Job (2003), ao afirmar que os fatores de risco, na esfera profissional, referem-se aqueles que fragilizam as condições de trabalho dos indivíduos, como foi o caso de Espedito Seleiro. Observa-se também que Espedito Seleiro enfrentou a situação utilizando como um de seus fatores de proteção a religiosidade, ao relatar sua crença em Deus como recurso para lidar com os impactos da situação. Dessa forma, nota-se que ele foi capaz de conseguir administrar a própria subjetividade e compreender a situação para se defender, como bem apontam Barlach (2005) e Barlach e Malvezzi (2010).

Espedito Seleiro ainda acrescenta que, na medida em que foi se tornando reconhecido por seu trabalho, às dificuldades relacionadas à falta de capital para investir foram sendo dissipadas, pois conquistou amizades junto aos fornecedores e seu reconhecimento gerou credibilidade:

Hoje não falta mais dinheiro porque eu tenho conhecimento, o meu conhecimento é grande. [...] Aonde eu tô acostumado a comprar matéria-prima eu, tanto faz eu ter dinheiro como não ter, eu compro material. [ ...] Se eu tiver com dinheiro aqui eu compro o material se não tiver, eu tenho aonde mandar pegar, basta ligar que eles mandam deixar (sic.).

Outro obstáculo foi a falta de reconhecimento no início da carreira: “quando eu comecei era difícil. Difícil mesmo porque num tinha gente de fora pra vir comprar e num tinha muito trabalho pra gente fazer por isso 
[...]". Para superar esta fase, o artesão explica que se dedicou ao máximo às suas criações: "quando eu comecei a fazer as peças, eu fazia no capricho que era pra ver se arrumava cliente, né. Eu digo eu vou fazer bem feito que é pra eu arrumar bem muito (sic) cliente, pra nunca faltar". A qualidade do trabalho e o tempo trouxeram o reconhecimento e os clientes passaram a procurar seus produtos:

Aí que fiquei trabalhando e [o] povo foram levando pras região (sic), aí vinha gente de Pernambuco vinha gente de outros estados né [ ...]. Aí o pessoal dizia: rapaz eu vou mandar fazer esse arreio em Nova Olinda porque lá tem um cara bem novinho, o bicho é quase menino ainda, mas trabalha bom. Aí vinha pra cá, eu fazia o serviço e eles ficava (sic) bastante satisfeito e assim foi espalhando o conhecimento.

No entanto, com o passar dos anos, a venda de artigos para vaqueiros começou a cair, pois como explica Mestre Espedito, a vestimenta completa de couro tornou-se cada vez mais cara e os vaqueiros começaram a preferir trabalhar usando bicicletas, motos, carros e caminhões. Além disso, o ciclo de vida dos produtos era muito longo: "porque uma sela que eu fazia é trinta ano (sic) pra se acabar, uma sela. Aí você faz uma peça que atura (sic) trinta anos, aquilo é uma coisa que vai dar pouco futuro ao artista". Essa fase, segundo o artesão, foi marcada por dificuldades nas vendas. Em, 1971, após a morte do pai, o problema se agravou, pois, sendo o filho mais velho, responsabilizou-se pela criação dos irmãos mais novos. Assim, o artesão percebeu que era o momento de diversificar seu trabalho:

Peguei os desenho (sic) das selas, daquelas selas bonita (sic) que existia que era dos ciganos, era do fazendeiro, era do deputado, era do governador [ ...]. Peguei o desenho da sela e joguei pra cima das bolsa (sic), sandálias [ ...]. Mas graças a Deus, quando eu mudei o estilo pra fazer sandálias, sapato e bolsa, sapato pra quadrilha, sapato pra filme, bolas, essas coisas, aí foi esbrangindo (sic).

Mesmo diversificando o seu estilo, Mestre Espedito não deixou de fazer o que aprendeu com seus antepassados: selas, gibões, chapéus e luvas de vaqueiros. Mas ele enfatiza que as novas peças foram bem aceitas, de tal modo que as vendas não mais foram sua preocupação principal. Essa passagem do relato de Espedito reforça o argumento defendido por Beck (2007), ao afirmar que os indivíduos, frente a fatores de risco para suas vidas, mobilizam o próprio conhecimento para lidar com as incertezas e, assim, conseguem desenvolver novos maneiras para pensar e realizar o seu fazer.

\subsection{Maria de Lourdes}

Maria de Lourdes Cândido Monteiro (Maria Cândido) nasceu em Pernambuco, em 1939. Reside em Juazeiro do Norte-CE, onde exerce suas atividades profissionais como artesã na tipologia barro ou cerâmica. Destaca-se pela produção de temas que retratam cenas do cotidiano nordestino. Foi diplomada Mestre/Tesouro Vivo da Cultura em 2004. Ao longo de sua carreira como artesã, Dona Lourdes enfrentou e ainda enfrenta algumas dificuldades, tais como o transporte das peças até o local de vendas, a ausência de formação escolar básica e a sazonalidade de vendas.

Transportar as peças para o centro de Juazeiro do Norte, onde estas eram comercializadas era a maior dificuldade enfrentada por Maria Cândido no início da carreira, já que a mesma residia na zona rural do município: “a dificulidade (sic) maior era essa da gente transportar pra cá que tinha que vim a pé". Em 1997, como uma tentativa de sanar o problema, a artesã decidiu mudar-se para o centro de Juazeiro do Norte, onde vive até hoje:

Aí eu me astrevi (sic) e vim pra cá morar dentro de Juazeiro que facilitou tudo. Se é pra associação, tirou daqui pra ali, é bem pertinho. Se é pra viajar pra fora, a gente faz as peças, pinta, embala, tira a nota fiscal, liga pra transportadora ela vem, pega e leva pra qualquer canto do mapa, onde for preciso. Aí facilitou bastante porque no sitio tudo era difícil.

A decisão de Maria Cândido de se mudar para o centro de Juazeiro do Norte, como alternativa para preservar o andamento de seu trabalho, vai ao encontro da declaração de Yunes e Szymanski (2001) em relação ao fato de que, frente às situações de risco, as pessoas tomam suas decisões e, por conseguinte, desenvolvem novos meios para realizar suas ações, em face de seus diferentes momentos de vida.

A sazonalidade de vendas foi outro desafio a ser enfrentado pela artesã:

[...] se por acaso nunca faltasse encomenda, não, a vida era ótima, era muito bom. Mas como a encomenda não é diariamente, às vezes no ano tem gente que encomenda duas, que faz duas encomenda (sic.), às vezes tem gente que só faz uma no ano. Aí é o tempo que a gente faz e entrega e vai ficar parado (sic.).

Assim, Maria Cândido afirma que há períodos em que o número de pedidos cresce e que já houve épocas melhores: “assim pro natal, mas olha agora no natal não chegou nenhuma ainda. Já era tempo da gente ter feito muita encomenda e ter até mandado né. Era o tempo que mais chegava encomenda pra nós era o natal". No ano de 2008, como ela explica, recebeu mais encomendas que no ano de 2009: "Recebemos, quatro encomendas do Rio de Janeiro, foi uma venda boa mesmo. [ ...] Valia muito a pena, viu"! E agora ela explica que "o pessoal vem faz uma encomenda de três ou quatro, mas é isso mesmo. A gente espera um dia melhorar". 
A imprevisibilidade vivenciada por Maria Cândido em relação às demandas pelas peças que produz, reforça a ideia articulada por Beck (2007) de que a vida contemporânea está constantemente permeada pelo trato e vivência das incertezas e insegurança nas mais distintas esferas da vida em sociedade. Neste caso, essa vivência das incertezas se deu na dimensão profissional da vida da artesã.

Atualmente, a principal adversidade vivenciada por Maria Câncido é suprir a lacuna da ausência de educação básica: “o problema mais, a dificulidade (sic) maior pra mim é o estudo [...] Depois de velha, a vontade que eu tenho de aprender, só Deus sabe. Mas ele tá me ajudando". Neste caso, Maria Cândido destaca que o simples fato de saber ler, escrever ou fazer contas simples já Ihe seria muito útil:

E como facilita porque quantas vezes a gente trabalha aqui e chega uma pessoa vem comprar e diz: pronto, faça a conta. Fazer o quê? Eu sei lá de conta? Como é que a pessoa sem saber ler sabe fazer uma conta? Não né comigo não. Eu digo só o tanto de peça, o preço da peça e resolvem lá (sic).

A educação deficitária de Maria Cândido lhe aparece como um fator de risco para sua vida, sobretudo, no aspecto profissional. Essa situação enfatiza as afirmações de Beck (2007) quanto ao fato de no indivíduo emergir sentimentos negativos na experimentação do risco. Neste caso, nota-se que, em Maria Cândido, é perceptível um sentimento de descontentamento em relação as suas limitações para desenvolver as habilidades de leitura, escrita e cálculo para o melhor exercício de seu trabalho.

\subsection{Dona Francisca}

Francisca R. Ramos do Nascimento (Dona Francisca) nasceu em Viçosa do Ceará-CE, em 1939, local onde ainda reside em uma comunidade chamada Sítio Tope. A artesã confecciona bonecas, baianas, presépios e jarros decorativos. Foi diplomada Mestre/Tesouro Vivo da Cultura em 2005. Dentre os problemas enfrentados na carreira, Dona Francisca destaca a dificuldade no transporte das peças, a forte concorrência local, as condições precárias de produção das peças, os conflitos entre os artesãos que compõem a associação do Sítio Tope e a necessidade de criar uma marca ou registro do trabalho da associação.

Especificamente em relação ao transporte da produção, até as feiras locais, no início da carreira, a artesã relata que: "[ ...] a gente levava as peça (sic) pra vender na Viçosa, na cabeça. [...] Mas pra gente ganhar mais um dinheirinho, né, a gente levava um pote na cabeça e um na mão". Conforme Dona Francisca, essa situação só se amenizou quando seus filhos cresceram e começaram a ajudá-la no transporte das peças.

Ao chegar às feiras, Dona Francisca afirma que tinha dificuldades para vender os produtos, pois muitas pessoas da região faziam potes e jarros, o que intensificava a concorrência local e dificultava a venda por um bom preço. Para vender mais, ela passou a abordar os clientes ainda no caminho da feira: “aí o que é que eu fazia, eu pegava um pote, botava um na cabeça, botava outro na mão e ganhava o rumo da onde tinha aquele pessoal que vinha comprar coisa na feira (sic)". Mais tarde, para aumentar as vendas, também passou a buscar por novos clientes em outras cidades, mas isso só foi possível quando seu marido adquiriu um animal: "aí foi aí que a gente comprou um jumentinho e meu marido pegava os pote, os jarro (sic) e ia vender fora [ ...]".

As condições precárias de produção foram outro desafio a ser superado pela artesã. Conforme Dona Francisca, a produção ocorria de forma muito precária até a chegada do apoio da CEART, em 1997. No preparo do barro, por exemplo, não havia local para estoque de matéria-prima e lenha, de modo que a artesã tinha apenas uma pequena quantidade desses itens. Segundo ela, os fornos eram inadequados, o que causava a quebra de peças, além de tornar o trabalho mais difícil durante o inverno, já que os mesmos não eram cobertos. Além disso, as artesãs costumavam trabalhar no chão, o que, ao longo do tempo, resultava em vários problemas de saúde em virtude da postura inadequada.

Nota-se que essa situação se apresentou como um potencial fator de risco cujos impactos recaem, sobremaneira, no desenvolvimento de problemas físicos ou até mesmo emocionais, como apontam Yunes e Szymanski (2001). Isto porque, como se percebe, Dona Francisca, enfrentou dificuldades importantes em relação os modos de produção requeridos em seu ofício. Esses fatores de risco seguramente fragilizaram, como indica Job (2003), as condições do próprio trabalho realizado.

Com o apoio da CEART e da Ação Social de Fortaleza, surgiram alguns conflitos entre os artesãos da comunidade. Em 1997, ano em que a CEART e a Ação Social de Fortaleza começaram a apoiar o artesanato no Sítio Tope, Dona Francisca afirma que tudo foi bem planejado e organizado: a forma de produção, a compra da matéria-prima, e as vendas. Mas quando a CEART começou a comprar as peças, houve alguns desentendimentos entre os artesãos. Isso porque o pagamento às vezes não era realizado no momento da entrega dos produtos, o que gerou insatisfação para alguns artesãos, acostumados a receber pelo pagamento no momento da compra. Outro agravante foi o fato de vários artesãos não compreenderem que o pagamento seria realizado por produtividade.

A insatisfação vivenciada pelo grupo de artesãos evidencia o quão as mudanças sociais modernas podem fazer emergir sentimentos negativos nas pessoas que as vivenciaram (Beck, 2007). É razoável reconhecer que esses artesãos vivenciaram uma condição de desequilíbrio emocional, como apontam Rutter (2007) e Brüseke (2001), frente ao fator de risco gerado pelo apoio do CEART a comunidade artesã. Pois, foi a partir das mudanças implicadas pelo aceite a esse apoio que muitos dos artesãos viram-se diante da necessidade de 
repensarem os seus modos de trabalho, seja no modo como pensam o seu ofício, ou propriamente, em relação ao modo como, de fato, o realizam.

A ausência de uma assinatura ou marca para os produtos ainda é um problema a ser superado, pois facilitaria a atuação dos atravessadores. Mestre Francisca ressalta que, certa vez, foi alertada sobre o fato de que outras pessoas estariam explorando seu trabalho:

Até que teve um homem que chegou de Fortaleza, eu tava lá e ele disse assim: você mora aonde? Eu moro no município de Viçosa chamado Tope. Aí ele disse Tope, em São Paulo tem peça desse lugar chamado Tope. Eu tô querendo dizer que é bom que vocês arranjem uma marca e bote a marca porque em cima disso, tem gente enricando. É nessas peça (sic) chamada Tope, gente enricando a custa das peças de vocês. E até mesmo aqui em Fortaleza.

Mesmo assim, ela explica que suas peças e das demais artesãs não são assinadas e que esperam pela iniciativa da CEART para criar uma marca para os produtos da região: "desde quando começou esse trabalho com a CEART que eles prometeram de mandar uma, de ter um selo, uma marca e nunca foi dado. As peça (sic) daqui pode ir lá pra num sei pra onde, foi feito aqui e num tem nada". Além disso, as demais dificuldades relacionam-se ao estado de saúde de Dona Francisca, que a impede de continuar produzindo em um ritmo mais acelerado como costumava fazer, embora a mesma ressalte que não deseja parar de trabalhar como artesã:

Porque eu num tô trabalhando mais muito assim porque eu tô com problema de saúde [ ...] Até 2007 eu ainda trabalhava muito. De 2008 pra cá foi que eu fui ficando assim mais doente [ ...] aí os médico começaram a dizer que eu tinha que diminuir o meu trabalho, né. [ ...] Só se eu tiver doente sem ter mais que pegar em barro, aí eu deixo mas enquanto não, eu sempre fico fazendo minhas boneca porque eu gosto.

A diferença no ritmo de trabalho apontado por Dona Francisca frente aos seus distintos estados de saúde ressalta a afirmação de Yunes e Szumanski (2001) de que a forma como os indivíduos significam a experimentação de um fator de risco em suas vidas, em muito, está atrelado aos diferentes momentos de suas vidas. Neste caso, o elemento determinante na experimentação do risco na carreira de Dona Francisca decorreu de sua condição de saúde.

\subsection{Lúcia Pequeno}

Lúcia Rodrigues da Silva (Lúcia Pequeno) nasceu em 1959, em Limoeiro do Norte-CE, onde ainda reside. Dedica-se ao artesanato em cerâmica, destacando-se pela produção de conjuntos de chá, jarras e vasos. Foi diplomada Tesouro Vivo da Cultura em 2004. No início da carreira, quando seu pai ainda era vivo, Lúcia Pequeno explica que o maior problema que enfrentava era transportar as peças produzidas até as feiras realizadas no centro de Limoeiro do Norte-CE: "todo sábado a gente levava, pagava uma carroça pra levar e tinha que pagar pra voltar". No entanto, a quantidade de peças era muito pequena e as vendas não eram suficientes nem para pagar o transporte.

Quando a procura pelas peças aumentou, Lúcia Pequeno passou a receber encomendas e parou de frequentar a feira, livrando-se, assim, deste problema: “porque a gente parou de levar pra feira e parou de pagar. Ficou só vendendo em casa. [ ...] Agora tá melhor. Antes era muito difícil [ ...] e agora não, nós vende (sic) tudo em casa". Sua opinião sobre as vendas é a seguinte: "tô, tá dando pra mim (sic) viver. A gente tendo um ganho que dê pra gente viver, é muita sorte porque é tão difícil o dinheiro de ser ganho, o custo de vida tá tão difícil. Tá dando pra mim viver (sic)".

As dificuldades vivenciadas por Lúcia Pequeno em relação aos problemas relacionados ao transporte de suas peças, bem como em relação à renda para manutenção de sua vida, remetem à afirmação de Jeolás (2010), quanto ao fato das pessoas possuírem maneiras distintas de expressarem o risco em suas vidas. No caso de Lúcia, embora o risco tenha sido expressado pela dificuldade de transporte de suas peças e os ganhos baixos e até mesmo insuficientes, em dado momento, ela ainda conseguiu encontrar maneiras de não sucumbir à situação, encontrando outra alternativa para vender suas peças e, portanto, de se relacionar com os impactos do tipo de trabalho que realiza. Além disso, a dificuldade para encontrar materiais utilizados na queima das peças é outro problema que acompanha Lúcia Pequeno desde o início da carreira e persiste até os dias de hoje.

agora o material de queimar sempre foi difícil. Pra gente buscar talo, talvez a gente andasse uns dois quilômetros pra trazer um cesto de talo na cabeça. A gente trabalhava demais, viu. A luta da gente pra fazer isso aí. É o custo de vida da gente aqui dá trabalho demais".

Assim, a artesã precisa adquirir esses materiais e, segundo a mesma, além do preço não ser muito acessível, há ainda dificuldades para encontrá-los. Esta escassez é vista como reflexo do desmatamento dos carnaubais, de onde provinham algumas das matérias-primas utilizadas em seu trabalho.

Outro problema mencionado pela artesã é o período chuvoso, no qual há uma queda de produção. Nesse período, Lúcia Pequeno interrompe ou reduz bastante a produção. Primeiramente, a extração do barro na lagoa torna-se mais difícil; depois, a queima das peças durante o inverno torna-se praticamente impossível, visto que o forno utilizado localiza-se no quintal. Nestes períodos, a artesã até chega a confeccionar algumas peças, as quais são estocadas, a espera dos dias em que não chova, embora as perdas sejam grandes: “no que o forno tá 
molhado de levar chuva e o material, a gente queima e é um prejuízo total. Aproveita muita pouca coisa porque elas quebram com a quentura do forno e o molhado, aí elas se racham tudinho dentro do forno".

Essa dificuldade enfrentada por Lúcia Pequeno em relação ao período chuvoso, o qual dificulta o trabalho da artesã na queima das peças, evidencia a afirmação de Beck (2007), de que diante dos fatores de risco o indivíduo lida com decisões ambíguas nas quais pondera sobre possíveis perdas ou ganhos com a situação. Esse comportamento é perceptível em Lúcia em face de suas ponderações acerca da necessidade de queimar as peças, pois com o forno molhado, existe a potencial ameaça das peças se danificarem, o que Ihe causaria a perda total das obras.

Por várias vezes, Lúcia Pequeno recebeu promessas de prefeitos e secretários de cultura municipais, os quais Ihe prometeram a construção de uma cobertura para o forno utilizado, mas até agora, nada de concreto foi feito: "tem muita gente que não gosta de cultura não. Tem prefeito que não gosta não. [ ...] 0 pessoal parece que não liga muito pra gente desse trabalho de loiceiro (sic) não. Dão muito valor a loiceiro não, o povo não (sic.)".

Além das dificuldades citadas, a artesã acrescenta que tem passado por sérios problemas de saúde os quais tem prejudicado bastante a produção que, segundo ela, já não ocorria da forma como a mesma gostaria, visto que esta também se vê na obrigação de trabalhar como dona de casa, atividade que a impede de se dedicar mais ao artesanato.

\subsection{Pedro Balaieiro}

Pedro Alves da Silva (Pedro Balaieiro) nasceu em Maranguape-CE, em 1926. Atualmente, reside no distrito de Pernambuquinho, em Guaramiranga-CE, onde exerce suas atividades profissionais como artesão na tipologia cestarias e trançados, destacando-se por confeccionar chapéus, luminárias, porta alimentos e objetos decorativos. Foi diplomado Mestre/Tesouro Vivo da Cultura em 2006. Ao longo de sua carreira, Pedro Balaieiro destaca alguns dos problemas enfrentados ou que ainda enfrenta, como a ausência de um local adequado para vender e expor, a dificuldade para aumentar a produção, a falta de apoio para capacitar outros artesãos e o uso ilegal de seu nome.

Desde o início de sua carreira, Pedro Balaieiro sente a ausência de um local fixo para expor e vender suas peças no município onde reside. Segundo ele, vários políticos locais já prometeram ajuda, a qual ainda não chegou:

Lá em Fortaleza tem a CEART [ ...] mas aqui na minha cidade que é Guaramiranga, eu tenho batalhado e pelejado pra conseguir um armarinho pra eu colocar o meu trabalho pra ser aberto todo dia, o pessoal passar, num é só pra comprar, como ver, que tá divulgado bastante e eu num tenho. [ ...] Já fizeram um em Guaramiranga e eu não recebi. Agora com mudança de político, tão prometendo de fazer um em Guaramiranga e fazer aqui [ Pernambuquinho] mas eu num vou me confiar não que de promessa eu já tô bem cheinho.

O fato de não possuir um espaço próprio para exposição e venda de suas obras, faz com que Pedro Balaieiro demonstre a vivência de certos sentimentos negativos frente à situação, tal como destaca Beck (2007). Neste caso, emerge um sentimento de descrença frente às promessas de políticos para solução desta situação.

Atualmente, Mestre Pedro destaca que seu principal desafio é a ausência de outros artesãos que possam trabalhar com ele e, assim, aumentar a produção: "podia vender mais se eu tivesse alguém que trabalhasse junto comigo. É aquela história da andorinha é uma verdadeira certeza". Essa maior capacidade produtiva significaria a possibilidade de aceitar encomendas maiores, o que não ocorre atualmente por falta de mão-deobra: "chega pedido de três milheiro (sic) e eu nunca tenho ninguém pra socorrer o pedido porque a maior parte do pessoal querem receber dentro daquele prazo aquela quantidade".

Para amenizar esta questão, ele chega a ministrar cursos e pequenas oficinas a quem deseja aprender o seu ofício. No entanto, o mesmo afirma que esta capacitação está longe de atender às suas expectativas, pois os aprendizes desejam uma espécie de bolsa ou ajuda de custo durante o aprendizado, o que ele não tem condições de oferecer. Segundo o artesão, o aumento de aprendizes também poderia ser uma fonte de renda para a comunidade, pois, as encomendas poderiam ser partilhadas: "porque muitas vezes a pessoa vem e quer a quantidade de peça e eu não tenho. Já tendo quem tenha, já manda pra eles pegarem lá".

A atitude de Mestre Pedro em pessoalmente ensinar aos jovens da comunidade o seu ofício, configura um fator de proteção por ele mobilizado para lidar com a situação. Desse modo, reafirma-se o entendimento de Barlach (2005) e Barlach e Malvezzi (2010) de que o indivíduo é capaz de administrar a própria subjetividade e compreender a situação para se defender, utilizando, para tanto, distintos fatores de proteção, como apontado por Job (2003).

Outro aspecto mencionado é a queda nas vendas locais. Estas, segundo Pedro Balaieiro, estão fracas na região de Guaramiranga-CE, embora a cidade seja turística. Mesmo sentindo-se satisfeito com as vendas atuais, ele explica que já passou por épocas melhores: “tá bem, mas tem uns tempo melhor. Já teve épocas melhores [...] Tô satisfeito porque eu já posso me considerar uma pessoa vivida que isso daí é vida, com o que aconteceu 
comigo". Para além das vendas, Pedro Balaieiro destaca ainda que o uso de seu nome sem autorização é uma prática comum na região:

O apelido de Pedro Balaieiro tá sendo tão importante que já tem gente comercializando usando meu nome, sem eu ter nada lá. É uma tristeza [...] roubar meu nome e dizer que é o meu trabalho aí é errado, né. Mas é tanto eles como as lojas que tem em Guaramiranga, eles têm mania de fazer isso.

Sobre este ponto, o artesão sabe que precisa identificar suas peças, como uma forma de amenizar o uso ilegal de sua assinatura. Entretanto, ressalta que ainda não tem condições de fazer isso: “mas pelo meno (sic) nem aqui as minha peça (sic) que eu tô fazendo, nem a etiquetazinha d'eu colocar da onde ela tá saindo eu não tenho por enquanto agora. [ ....] Eu não tenho e tô precisando".

\subsection{Dona Nice $^{2}$}

Maria de Castro Firmeza (Dona Nice) nasceu em Aracati-CE, em 1921, mas residia há muitos anos em Fortaleza-CE, onde exerceu suas atividades profissionais como artesã, artista plástica e arte-educadora. Destacou-se por bordar blusas, vestidos e toalhas com desenhos exclusivos, criados por ela mesma. Foi diplomada Mestre/Tesouro Vivo da Cultura em 2007. Dona Nice salientou que não enfrentou grandes problemas e dificuldades em relação à carreira de artesã. Na verdade, ela passou a exercer essa atividade de forma secundária, visto que seus primeiros interesses voltaram-se para o teatro e as artes plásticas. No entanto, esses interesses fizeram com que Dona Nice se deparace com a oposição familiar, principalmente do irmão: "nas peças eu não enfrentei não, mas o meu irmão eu enfrentei. Ele ficou tão zangado, era o mais velho, tava no lugar do meu pai, meu pai tinha morrido. Ele quem resolvia tudo pra nós, quem pagava colégio, quem fazia tanto [...]".

Sua família mostrava-se contrária às atividades artísticas que Dona Nice escolhia, principalmente o teatro: "mas quando meu irmão veio a Fortaleza e soube, me tirou do colégio. Gente de família num queria negócio de teatro". A mesma postura era demonstrada quando a mesma passou a frequentar os cursos de artes-plásticas. No entanto, Dona Nice buscou um emprego como telefonista, como uma forma de reduzir a oposição da família à pintura e também para ter recursos para adquirir os materiais que necessitava:

Isso porque meu irmão [ disse]: você só quer seguir carreira que não interessa. Porque o pessoal acha que tem que ser ou dentista ou médico ou advogado, só essas carreira, a arte não é, e eu queria era arte [...]. Eu já tava com vinte e poucos anos, eu tava no dentista quando eu vi [que]: a Telefônica tá precisando de funcionário. Eu nem esperei o dentista. Fui bater lá [ ...].

As dificuldades enfrentadas por Dona Nice em relação à reação negativa de sua família sobre suas predileções profissionais foram amenizadas por sua decisão em conciliar as atividades artísticas com o trabalho de telefonista. Percebe-se que essa decisão de trabalhar em uma atividade fora da esfera artística foi mobilizada por ela como um fator de proteção (Job, 2003), frente ao risco gerado pela não aceitação da família por sua carreira no campo das artes.

As outras dificuldades e desafios por ela enfrentados relacionam-se às ocupações de artista plástica e de educadora infantil e não à atividade artesanal, principalmente porque suas peças (bordados) eram confeccionadas. Dona Nice afirma enfrentar dificuldades para manter o minimuseu que fundou com o marido, pois não recebe apoio algum e toda a manutenção do local é realizada às suas próprias custas e de seu marido. Dessa maneira, ela e o marido se preocupam quanto ao futuro do museu e a mesma ressalta que ambos gostariam que o Governo do Estado adquirisse seu acervo:

Então ele tinha [ o marido de Dona Nice] vontade de se o Governo do Estado comprasse e fizesse um museu, podia ser ou alugava a casa com o museu [ ...] ou comprasse só os trabalho, eles tem prédio onde botar. Porque o nosso museu é História da Arte do Ceará. Se a pessoa quiser saber quem são os pintores que merecem estar no museu, está aqui.

A atividade artesanal de Dona Nice parece não ter sido voltada para a sua sobrevivência, já que a mesma possuía uma situação financeira mais confortável em relação aos demais sujeitos desta pesquisa. Por este motivo, o bordado surgiu em sua vida mais como um hobby e não como um trabalho em si, embora a mesma enfatize que atendeu muitas encomendas, basicamente de pessoas conhecidas e próximas a ela. A artesã destaca que passou a bordar mais por insistência dos clientes e nem tanto por vontade própria: "então eu fazia mais era porque as pessoas queriam, né". Dessa forma, o bordado significou uma atividade que gerou uma renda complementar, mais pela identificação e paixão com que a mesma se dedicava a esta atividade do que por uma necessidade de retirar desta ocupação o seu sustento ou pela vontade de transformá-la em um negócio. É nesse sentido que a forma com que Dona Nice lida conduziu as suas atividades na carreira criativa, frente aos demais entrevistados nesta pesquisa, reforça os argumentos de Rutter (2007) e Reppold et al., (2012), quanto à experimentação do risco ser vivenciada de maneiras muito distintas entre os indivíduos inseridos em uma mesma situação.

A seguir, apresentamos a Figura 2, que sintetiza as informações pertinentes à experimentação do risco vivenciada pelos entrevistados na dimensão profissional de suas vidas. Ou seja, indicaremos quais foram os 
fatores de risco enfrentados, bem como quais foram os fatores de proteção mobilizados pelos artesãos frente às situações vivenciadas.

\begin{tabular}{|c|c|c|}
\hline \multicolumn{3}{|c|}{ Síntese da Experimentação do Risco na Vida Profissional } \\
\hline Artesão & Fatores de risco enfrentados & Fatores de proteção mobilizados \\
\hline Espedito Seleiro & $\begin{array}{l}\text { Capital insuficiente para investir no } \\
\text { próprio trabalho }\end{array}$ & $\begin{array}{l}\text { (i) religiosidade } \\
\text { (ii) mobilizar conhecimento para } \\
\text { enfrentar as incertezas do ofício }\end{array}$ \\
\hline Maria de Lourdes & $\begin{array}{l}\text { Imprevisibilidade de demanda de trabalho } \\
\text { Condições precárias de produção } \\
\text { Educação deficitária }\end{array}$ & $\begin{array}{l}\text { (i) mobilizar conhecimento para } \\
\text { enfrentar as incertezas do ofício } \\
\text { (ii) mudar de cidade para venda das } \\
\text { peças }\end{array}$ \\
\hline Dona Francisca & $\begin{array}{l}\text { O episódio de apoio estabelecido pela } \\
\text { CEART } \\
\text { Estado de saúde }\end{array}$ & $\begin{array}{l}\text { (i) desenvolver alternativas para } \\
\text { vendas das peças }\end{array}$ \\
\hline Lúcia Pequeno & $\begin{array}{l}\text { Dificuldade para transportar as peças } \\
\text { produzidas } \\
\text { Período de chuvas }\end{array}$ & $\begin{array}{l}\text { (i) desenvolver alternativas para } \\
\text { vendas das peças }\end{array}$ \\
\hline Pedro Balaieiro & $\begin{array}{l}\text { Não possuir local próprio para exposição } \\
\text { do trabalho }\end{array}$ & $\begin{array}{l}\text { (i) ensinar o ofício de artesão aos } \\
\text { jovens e à comunidade }\end{array}$ \\
\hline Dona Nice & $\begin{array}{l}\text { Falta de apoio da família em relação ao } \\
\text { trabalho artístico }\end{array}$ & $\begin{array}{l}\text { (i) buscar atrelar a realização do } \\
\text { trabalho de artesã com outra atividade } \\
\text { profissional }\end{array}$ \\
\hline
\end{tabular}

Figura 2 - Síntese das informações pertinentes ao conjunto de entrevistados da pesquisa

Fonte: Dados da pesquisa (sistematizado pelos autores).

\section{Discussões Conclusivas}

Desenvolvemos este estudo a partir do seguinte questionamento: como os artesãos da indústria criativa do artesanato experimentam o risco em suas vidas profissionais? Esta questão nos fez estabelecer, como objetivo da pesquisa, investigar a forma como o risco é experimentado em carreiras criativas. Para responder ao problema de pesquisa, procuramos sistematizar o conhecimento existente sobre o tema. Além disso, utilizamos como dados empíricos de aporte a pesquisa, os relatos das experiências de artesãos detentores do título de "Mestres da Cultura Tradicional Popular" concedido pelo Governo do Estado do Ceará. Por meio da articulação entre os preceitos teóricos e os dados empíricos, atingimos o objetivo desta pesquisa. Indicamos, a seguir, as principais questões e aspectos observados ao longo desta investigação.

Em primeiro lugar, esta pesquisa buscou evidenciar como a noção de risco se apresentou em todas as micro-biografias apresentadas no estudo. Esse esforço de pesquisa se constituiu por meio da interface entre os relatos empíricos coletados - junto aos artesãos - com as premissas teóricas levantadas sobre o conceito de risco e o construto carreiro no âmbito da indústria do artesanato. Ainda assim, sabemos que qualquer tentativa de apreender o fenômeno da experimentação do risco na carreira criativa pode incitar questionamentos como: em que medida podemos distinguir a percepção de risco oriunda dos sentidos atribuídos exclusivamente pelos entrevistados da pesquisa, do modo como os pesquisadores do estudo, em si, escolheram interpretar o fenômeno?

Há de se esclarecer que qualquer esforço de pesquisa empírica não está à luz de confirmações teóricas pura e simplesmente. Entendemos que pesquisas dessa natureza possuem per si uma abertura natural para se deparar com o novo e com o desconhecido. Esta possibilidade reside exatamente em uma espécie de via de mão dupla. Por um lado, temos indivíduos disponíveis em relatar fatos de suas vidas, relatos estes que viram a constituir as evidências empíricas de um estudo. Por outro, existe o interesse sincero dos pesquisadores em vislumbrar, por meio dessas evidências, articulações teóricas capazes de aperfeiçoar e desenvolver a compreensão sobre o assunto investigado.

De certo, este processo só é possível caso os pesquisadores já partam de um aporte teórico que os oriente a um modo apropriado para se abordar a questão. É deste conhecimento prévio que serão elaboradas as questões a serem feitas aos entrevistados os quais, por sua vez, irão articular suas falas e pensamentos sobre o assunto a partir das perguntas a eles realizadas. É a partir das respostas obtidas que o pesquisador, por meio de sua maneira de olhar o fenômeno, conseguirá acessar - em alguma medida - o universo vivenciado pelos entrevistados. Em boa medida, é a partir das questões feitas pelos pesquisadores aos entrevistados que estes últimos conseguiram se posicionarem - de algum modo - perante ao escopo de pesquisa que motivou esse contato entre pesquisadores e entrevistados.

Por esse motivo, nesta pesquisa, acreditamos que os resultados obtidos emergiram de uma colaboração profícua entre os sentidos atribuídos nas falas dos próprios entrevistados e do modo de interpretar dos pesquisadores. Esse modo do fazer acadêmico de pesquisa, reflete apenas a nossa convicção de que em qualquer estudo de campo é inevitável que exista certo grau de participação entre os entrevistados e os pesquisadores, porque a dicotomia atribuída aos diferentes modos de enxergar um determinado fenômeno é de fato um continuum que constitui todo o processo de interação entre pesquisador e pesquisado em uma investigação. 
Em segundo lugar, para tecer os resultados mais pontuais desta pesquisa, é apropriado reiterar que a experimentação do risco na carreira criativa consiste de uma relação dual entre o que vem a ser um fator de risco ou um fator de proteção para um indivíduo. Isto porque, como esclarecemos na fundamentação teórica deste trabalho, a percepção de ameaça frente ao risco advém dos significados que a pessoa atribui aos eventos estressantes que vivencia, de modo que uma mesma situação pode provocar diferentes impactos sobre os indivíduos. Não por acaso, nesta pesquisa, percebemos que o risco foi experimentado de modos muitos distintos pelos artesãos, a começar pelo fato de terem surgido, em seus relatos, diferentes fatores de risco, a saber: capital insuficiente para investir no próprio trabalho (Espedito Seleiro); imprevisibilidade de demanda de trabalho (Maria de Lourdes); educação deficitária (Maria de Lourdes); condições precárias de produção (Maria de Lourdes); o episódio de apoio estabelecido pela CEART (Dona Francisca); estado de saúde (Dona Francisca); dificuldade para transportar as peças produzidas (Lúcia Pequeno); período de chuvas (Lúcia Pequeno); não possuir local próprio para exposição do trabalho (Pedro Balaieiro); e, a falta de apoio da família em relação ao trabalho artístico (Dona Nice).

Para lidar com esses fatores de risco, os artesãos lançaram mão de alguns fatores de proteção, tais como: religiosidade (Espedito Seleiro); mobilização do conhecimento para enfrentar as incertezas do ofício (Espedito Seleiro e Maria de Lourdes); mudança de cidade para venda das peças (Maria de Lourdes); desenvolvimento de alternativas para vendas das peças (Dona Francisca e Lúcia Pequeno); ensino do ofício de artesão aos jovens e à comunidade (Pedro Balaieiro); e tentativa de atrelar a realização do trabalho de artesã com outra atividade profissional (Dona Nice).

O fato é que a manifestação do risco na vida dos artesãos ora se deu de modo mais coletivo ora de maneira mais individualizada. Contudo, foi a partir da forma como cada um deles compreendeu e significou os fatores de risco que os graus dessa experimentação assumiram níveis maiores ou menores de impacto em suas carreiras. Esses resultados nos levam a concluir que, embora haja divergências nos fatores de proteção mobilizados pelos artesãos para lidarem com o risco em suas vidas profissionais, eles encararam e guiaram seus comportamentos frente a essa experimentação de modos muito similares, na medida em que conseguiram ressignificar a situação, enxergando-a com um novo olhar. Assim, conseguiram se adaptar aos impactos da carreira e até mesmo criar novas possibilidades de exploração da mesma, pois praticamente todos inovaram em suas peças, criando particularidades e imprimindo-Ihes a sua assinatura artística, o que Ihes gerou um diferencial em relação aos demais artesãos.

Há de se observar ainda que, apesar de serem incertos os limites cronológicos que configurem a contemporaneidade, sabemos que o recorte deste trabalho pode gerar um questionamento sobre o fato da noção de sociedade de risco não refletir diretamente a realidade dos artesãos entrevistados. Isto porque, é certo que boa parte das carreiras desses artesãos ocorreu em um contexto temporal, espacial e profissional de contornos e direcionamentos mais tradicionais. No entanto, gostaríamos de ressaltar que, ao longo desta pesquisa, buscamos articular como a experimentação do risco se tornou uma característica marcante na dimensão profissional da vida contemporânea. Nesse sentido, admitimos que a vivência dessa experimentação avançou sobre todos os tipos de profissionais atuantes no mercado sejam eles jovens ou experientes. Isto porque independente de qual estágio de carreira os profissionais estejam vivenciando, o cenário contemporâneo tem Ihes demandado lançarem mão de novas maneiras para se pensar e sentir o próprio fazer diante das situações que se impõem como inevitáveis para manter o exercício da vida produtiva.

Sendo assim, por mais que os artesãos entrevistados nesta pesquisa tenham desenvolvido boa parte de suas carreiras em um contexto temporal, espacial e profissional de contornos e direcionamentos mais tradicionais, não podemos negligenciar o fato de que os relatos coletados desses entrevistados refletiram não só suas experiências profissionais do passado - que em boa medida também emergiram diante à experimentação de situações de risco - mas igualmente revelaram o modo como eles acabaram lidando com as novas circunstâncias profissionais intensificadas nos últimos anos. Nesse sentido, buscamos apontar que embora a noção de risco possa ser perceptível na vida profissional dos artesãos entrevistados em cenários anteriores, talvez a diferença resida no fato de que essa noção - embora estivesse presente ao longo de suas carreiras - não fosse tão evidente no passado.

Essa conclusão ressalta, portanto, aspectos que vão além da adaptação dos artesãos a experimentação do risco para sobrevivência e para a participação em uma sociedade capitalista. Ao mesmo tempo, mostram que a complexa formação de um grupo profissional, nesse caso, do campo das atividades artísticas ou criativas, é permeada por um conjunto similar de fatores de risco em diálogo, sem com isto implicar homogeneidade para lidar com uma mesma situação inerente ao ramo de suas atividades produtivas. Foi dessa maneira que os artesãos: repensaram os seus modos de trabalho; descobriram alternativas para lidar com a experimentação do risco em suas vidas; encontraram maneiras para pensarem os significados de seu ofício; e, por fim, elaboraram modos alternativos para permanecerem na construção de suas carreiras criativas.

\section{Notas}

1- Agradecemos às significativas sugestões realizadas pelos avaliadores deste artigo, as quais contribuíram decisivamente para o aperfeiçoamento das ideias articuladas em nosso trabalho.

2- Aos 91 anos de idade, Dona Nice faleceu no dia 13 de abril de 2013. Dentro do possível, este artigo simboliza uma singela homenagem a esta mulher que foi uma das grandes artistas cearenses. 


\section{Referências}

Alves, M. G. (2009). Ensino Superior, Trabalho e Emprego na Actual Sociedade de Risco: Um olhar sobre o caso de mestres e doutores. Sociologia, Problemas e Práticas, 59, 107-124.

Barlach, L. (2005). O que é resiliência humana? Uma contribuição para a construção do conceito. 2005.108 p. Dissertação (Mestrado em Psicologia Social) - Instituto de Psicologia, Universidade de São Paulo. São Paulo - SP.

Barlach, L., Limongi-França, A. C., \& Malvezzi, S. (2008). O Conceito de Resiliência Aplicado ao Trabalho nas Organizações. Internamerican Journal of Psychology, 42(1), 101-112.

Barlach, L., \& Malvezzi, S. (2010). Human resilience: what is it? A conceptual review. Saarbrucken, Deutchland: VDM Verlag.

Barros, L. A. S. (2006). Design e Artesanato: as trocas Possíveis. 2006. 132 p. Dissertação (Mestrado em Design). Pontifícia Universidade Católica do Rio de Janeiro. Rio de Janeiro - RJ.

Bauman, Z. (2005). Vida Líquida. Rio de Janeiro: Jorge Zahar.

Beck, U. (2007). Risk Society: Towards a New Modernity, Londres: Sage Publications.

Bendassolli, P. F., \& Wood Jr., T. (2010). O Paradoxo de Mozart: Carreiras nas Indústrias Criativas. Organizações \& Sociedade, 17(53), 259-277.

Bluhm, D. J., Harman, W., Lee, T. W., \& Mitchell, T. R. (2011). Qualitative Research in Management: A Decade of Progress. Journal of Management Studies, 48(8), 1866-1891.

Bnb. (2002). Ações para o desenvolvimento do artesanato no Nordeste. 2. ed. Fortaleza: Banco do Nordeste.

Brüseke, F. J. (2001). A Técnica e os Riscos da Modernidade. Florianópolis: Editora UFSC.

Ceará. (2008). Edital dos “Tesouros Vivos da Cultura" 2008, para inscrição, seleção e titulação dos "Tesouros Vivos da Cultura” do Estado do Ceará. Diário Oficial do Estado do Ceará, Fortaleza, série 2, n. $92,19$.

Collis, J., \& Hussey, R. (2005). Pesquisa em Administração: um guia prático para alunos de graduação e pósgraduação. 2 ed. Porto Alegre: Bookman.

Cowan, P. A., Cowan, C. P., \& Schulz, M. S. (1996). Thinking about risk and resilience in families. In Hetherington, M. E., \& Blechman, E. A. (Orgs.). Stress, Coping and Resiliency in Children and Families, New Jersey: Lawrence Erlbaum Associates.

Cunlifee, A. L. (2011). Crafting qualitative research: Morgan and Smircich 30 years on. Organizational Research Methods, 14(4), 647-673.

DCMS. (2008). Creative industries mapping document. Department for Culture, Media and Sport (Departamento de Cultura, Mídia e Esporte do Reino Unido). Recuperado de http://www.culture.gov.uk/reference_library/publications/4632.aspx

DECON. (2008). Estudos para o desenvolvimento do Estado do Rio de Janeiro: a cadeia da indústria criativa no Brasil. Rio de Janeiro: DECON (Divisão de Estudos Econômicos), n. 2, 2008. Recuperado de http://tinyurl.com/489ymqe

Eikhof, D. R., \& Haunschild, A. (2006). Lifestyle Meets Market: Bohemian Entrepreneurs in Creative Industries. Creativity and Innovation Management, 15(6), 234-241.

Florida, R. (2002). The Rise of the Creative Class. New York: Basic Books.

Freitas, A. L. C. (2006). Design e artesanato: uma experiência de inserção da metodologia de projeto de produto. Dissertação de Mestrado, Escola de Engenharia da Universidade Federal de Minas Gerais, MG, Brasil.

Gil, A. C. (2002). Como elaborar projetos de pesquisa. 4. ed. São Paulo: Atlas.

Howkins, J. (2005). Understanding the Engine of Creativity in a Creative Economy: An Interview with John Howkins. Recuperado de http://tinyurl.com/4kh5xu8

IBGE. (2007). Perfil dos municípios brasileiros - Cultura. Recuperado de www.ibge.gov.br/home/estatistica/economia/perfilmunic/cultura2006/default.shtm

Jeolás, L. S. (2010). O diálogo interdisciplinar na abordagem do risco: limites e possibilidades. Saúde e Sociedade, 19(1), 9-21.

Job, F. P. P. (2003). Os sentidos do trabalho e a importância da resiliência nas organizações. 2003. Tese (Doutorado em Administração) - Escola de Administração de Empresas de São Paulo da Fundação Getúlio Vargas (EAESP - FGV). São Paulo - SP.

Lima, C. L. C. (2007). Políticas culturais para o desenvolvimento: o debate sobre as indústrias culturais e criativas. Anais do Encontro de Estudos Multidisciplinares em Cultura, 3o, Salvador, Bahia, Brasil. 
Lima, A. A. M., \& Azevedo, I. M. (1982). O Artesanato nordestino: características e problemática atual. Fortaleza: Banco do Nordeste/ETENE.

Marcus, C. (2005). Future of Creative Industries: Implications for Research Policy. European Commission. Belgium: European Communities.

Masten, A. S. (2007). Resilience in developing systems: Progress and promise as the fourth wave rises. Development and Psychopathology, 19, 921-930.

Masten, A. S., \& Garmezy, N. (1985). Risk, Vulnerability and Protective Factors in Developmental Psychopathology. In Lahey, B. B., \& Kazdin, A. E. (Orgs.). Advances in Clinical Child Psychology. New York: Plenum Press.

MDIC. (2002). MDIC e Sebrae lançam projeto do artesanato na BR 040. Ministério do Desenvolvimento, Indústria e Comércio. Recuperado de http://tinyurl.com/4hz8u43

Meihy, J. C.S. B. (2002). Manual de história oral. 4.ed. São Paulo: Edições Loyola.

Menger, P. M. (1999). Artistic labor markets and careers. Annual Review of Sociology, 25, $541-574$.

Mizruchi, S. (2009). Risk Theory and the Contemporary American Novel. American Literary History, 22(1), 109135.

Miles, M. B., Huberman, A. M. (1994). Qualitative data analyses. New York: Sage.

Paulilo, M. A. S. (1999). A pesquisa qualitativa e a história de vida. Serviço Social em Revista, $2(1), 1-8$.

Raffaelli, M., Koller, S. H., Cerqueira-santos, E., \& Morais, N. A. de. (2007). Developmental risks and psychosocial adjustment among low-income Brazilian youth. Development and Psychopathology, 19, 565-584.

Reppold, C. T., Mayer, J. C., Almeida, L. S., \& Hutz, C. S. (2012). Avaliação da Resiliência: Controvérsia em Torno do Uso Das Escalas. Psicologia: Reflexão e Crítica, 25(2), 248-255.

Rutter, M. (2007). Resilience, competence and coping. Child Abuse and Neglect, 31, 205-209.

Santamarina, C., \& Marinas, J. M. (1999). Histórias de vida e historia oral. In Delgado, J., \& Gutiérrez, J. (Orgs.). Métodos y técnicas cualitativas de investigación em ciencias sociales. Madrid: Síntesis.

Scholz, R. W., Blumer, Y. B., \& Brand, F. S. (2012). Risk, vulnerability, robustness, and resilience from a decisiontheoretic perspective. Journal of Risk Research, 15(3), 313-330.

SEBRAE. (2008). Artesanato: um negócio genuinamente brasileiro. v. 1, n. 1, 52. Recuperado de http://tinyurl.com/48thqhf

SECULT-CE. (2009). Tesouros Vivos da Cultura. Recuperado de http://www.secult.ce.gov.br/patrimoniocultural/patrimonio-imaterial/ mestres-da-cultura/tesouros-vivos-da-cultura

Silva, H. M. (2006). Por uma teorização das organizações de produção artesanal: habilidades produtivas nos caminhos singulares do Rio de Janeiro. 2006. 180 p. Tese (Doutorado em Administração). Fundação Getulio Vargas - EBAPE/FGV, Rio de Janeiro - RJ.

Throsby, D. (2001). Economics and culture. New York: Cambridge University Press.

Triviños, A. N. S. (2007). Introdução à pesquisa em ciências sociais: a pesquisa qualitativa em educação. São Paulo: Atlas.

UNCTAD. (2008). Creative Economy Report 2008. Recuperado de www.unctad.org/en/docs/ditc20082cer_en.pdf UNESCO. (1997). Final Report of the International Symposium on Crafts And The International Market: Trade and Customs Codification. Manila: UNESCO. Recuperado de http://unesdoc.unesco.org/images/0011/001114/111488Eo.pdf

Vergara, S. C. (2008). A resiliência de profissionais angolanos. RAP - Revista de Administração Pública, 42(4), 701-718.

Yunes, M. A. M., \& Szymanski, H. (2001). Resiliência: noção, conceitos afins e considerações criticas. In Tavares, J. (Org.). Resiliência e educação. 2. ed. São Paulo: Cortez. 